\title{
SPANISH GROUP OF SEDIMENTOLOGY
}

\begin{abstract}
$\mathrm{T}$ HE second (biennial) reunion of the Grupo Espanol de Sedimentologia was held in Sovillo, at La Escuola do Estudios Hispano-Amoric ınos, during October 16-21. The reunion was attonded by 28 Spanish scientists interested in sedimentology as geologists, mineralogists, pedologists and engineers, and was organized by the Consejo Superior de Investigaciones Ciontificas, Madrid, Sección de Petrografía Sedimentaria. D. F. Ball, of tho Naturo Conservancy, Bangor, attondod as an invited guest. The papers presented covered the wide fiold of approach to the subject of those participating.

'Techniques diseussed includod tho applications of phaso-contrast microscopy to soil mineralogy by Dr. M. Delgado (Granada); olectron microscopy studies of sediments of the Tagus basin by Dr. J. Alonso; differential thermal analysis of clays in podzols of Lugo Provinco by Prof. Muñoz Taboadela (Santiago) and X-ray fluorescence spoctrography by D. F. Ball. The methods of determining sanidine in sediments were reviewed by Dr. P. Arévalo.

Papers of particularly pedological significance included thin-soction studios of Andalusian braunlehm by Drs. N. Bellinfante and G. Paneque (Seville), investigation of opaline silica particles in soils and sediments from Eeija (Seville) by G. Panoquo and of distribution of major soil groups in Wales by D. F. Ball. The work on braunlehm fabric has shown that this is present at depth in Tertiary sediments in what would be considored $C$ horizon matorial and not only as a pedological product in the uppor horizons of the solum. Prof. González García (Seville) discussed trace oiomonts, particularly manganose and cobalt, in soils and sediments of Seville Province.

Some of the important geological contributions were thoso of Prof. O. Riba (Zaragoza) with Dr. Porez Mateos (Madrid) on the Tertiary and Quaternary sediments of the Huelva area, and of the same author on a palæogoographic roconstruction of tho Ebro basin. This utilized heavy-mineral studies and a statistical investigation of mica-oriontation in crossbedded sands to determine direction of flow of the depositing currents. Tho identification of loess as occurring in Toledo Province was described by Dr.
\end{abstract} J. Benayas (Madrid). I.r. L. Alias Perez and Dr.
Rodrigue\% Gallogo (Granada) gave accounts of work on the sand and clay fraction of sediments carried by rivers draining the region of Granada.

Goological studies linking sedimentology with engineering problems included the papers of Prof. F. Hernández Pacheco and Dr. I. Asonsio Amor (University of Madrid) on the forces responsible for building the sund-bar and banks across the bay of Santandor. Their work showod that marino-eroded and current-borne sediments, rather than sediments derived from rivors draining into the bay, are the materials from which the bar and banks ure constructod. Somo of the first joint studies between sedimentologists and engineering geologists of borehole samplos from the Ebro delta were reported on by Sr. Macau Vilar (Ministry of Public Works), Prof. L. Solé Sabarís and Dr. C. Virgili (University of Barco. lona) and thoir collaborators. The problems involved in studying silting in reservoirs and behind dams were interestingly reviewed by F. Suároz Gómoz, who described methods for sampling sediment load in rivers and for measuring the bottom profile across rosorvoirs.

A field-tour visited areas near Huelva, in particular the extensive Almonte Forest, on cemented sands with what are probably relict podzol soils. 'The deep $A_{2}$ horizon of thoso, 99 por cont quartz sand in composition, forms the present surface soil. Relict peats occurring in basins within the sand are now boing exploitod. Fxperimental plots of such crops as beans, maize, and tomatoes were seen on irrigatod sandy soils with which this peat has been mixed. Interosting rosults are being achieved on this field-trial scale; for example, tomatoes planted at the beginning of Septomber had well-developed fruit by mid-October. Orange trees planted in peat-filled boles were showing good early growth.

Tho full proceedings of this reunion will be published as II Reunión de Sedimentologia, by the Instituto do Edafologia, Serrano 113, Madrid (6). The third reunion of the group is pianned for Santiago, north-west Spain, in the summer of 1963. Details can be obtained from Prof. Muñoz Taboadola, Depart mont of Applied Geology, University of Santiago, Spain.
David F. Baxi

\section{MEASURING PRODUCTIVITY OF NORTH AMERICAN DUCKS}

\begin{abstract}
A $\mathrm{N}$ evaluation of sex and age ratios in North American duck populations and the ways in which, in waterfowl management, these ratios can be used to measure productivity has been carried out by Frank G. Bellrose, Thomas G. Scott, Arthur S. Hawkins and Jessop B. Low*. Determination of sex composition in duck populations presented a difficult sampling problem which was complicated by differences in species, seasons and places, and by

- State of Iulnols: Department of Reglstration and Education. Natural History Survey Division. Bulletin, Vol. 27, Article 6 (August 1961): Sex Ratios and Age Ratios in North A merican Ducks. By F. C. Bellrose, T. G. Scott, A. S. Hawking and J. B. Low. Pp. vi + Natural History Survey Division, 1901.) 1 dollar.
\end{abstract}

inadequate sampling techniques. Most trapped or bagged ducks that could not be readily sexed by differences of plumage were sexed by cloacal characters. Four methods of sampling waterfowl populations for sex ratios were used: (1) examination of trapped ducks, (2) inspection of ducks taken by hunters, (3) observation of ducks in the field, and (4) examination of disease victims.

Baited, funnel-type traps tended to take disproportionate numbors of drakes, while gate-type traps placed on shore tended to catch a predominant number of hens. Inspection of ducks in hunters' bags made possible the separation of drakes and hens in moulting adults and in juveniles. Most sex ratios 
derived from inspection of hunters' bags showed little bias, usually in favour of drakes.

Analysis of available data showed no significant departure from an evenly balanced sex ratio in ducks at fertilization or at hatching. Data obtained from examining juvenile ducks trapped during the breeding season or taken by hunters during autumn indicated that the ratio between sexes from the time of hatching to adulthood was close to $50-50$; local variations appeared to result from differences in seasonal move. ments. Although sex ratios of adults usually favoured. drakes, there were, however, numerous exceptions. Sex ratios of many species of ducks varied from woek to week in any given area as the composition of the local population changed with the arrival and departure of flocks containing varying numbers of irakes and hens.

In most species of ducks for which data were available, drakes made up a smaller proportion of the hunters' kill in Manitoba than in three States to the south (North Dakota, Illinois and Tennessee), indieating that more drakes than hens left Manitoba in advance of the hunting season. Periodic counts of ducks in late winter and early spring revealed differences in the sequence of northward migration of drakes and hens of the same species. The first spring flights arriving in Manitoba showed a closer approach to a balance between sexes than did subsequent populations.

Information collected on the principal mortality factors affecting the North American duck population indicates that hunters and disease take relatively more drakes than hens. The information is not sufficient to permit appraisal of the influence of predation on sex ratios. However, appreciable losses among hens during the breeding season, most of these losses apparently being attributable to predation, agricultural operations, and stress, may account for the predominance of drakes in the adult class. The more productive a species of waterfowl, the greater is apt to be the proportion of juveniles in its population at the opening of the hunting season; the greater the proportion of juveniles in a population, the more nearly balanced is its sex ratio.

Drakes occurred in relatively greater numbers among diving ducks than among dabblers; examina. tion of the available knowledge on the reproductive biology characterizing these two sub-families revealed nothing which suggests that extra drakes may be more important to the maintenance of populations of diving ducks than of dabblers.

The authors also showed that age ratios alone are seldom true indices of waterfowl production, but they offer a promising basis for measuring it. Age ratios derived from waterfowl lost to severe outbreaks of disease were considered unreliable because of irregular occurrence and site limitations. Because juveniles and adults do not follow identical migration schedules or routes, age ratios showed seasonal and regional variations. Age ratios were found to be useful for appraising the production of ducks if the data on which they were based had been carefully evaluated to show the effect of seasonal, regional, and shooting biases.

An attempt was made to correlate water conditions on the breeding grounds with mallard production. In Saskatchewan, mallard production (as determined by the number of juveniles per adult among birds bagged in Illinois) and water abundance (as measured by the number of ponds per square mile in May) followed similar trends in most years of the period 1948-59. In Manitoba, mallard production tended to parallel water abundance in the period 1956-59 but not in the three previous years. Decreased production by the mallard on the plains of Canada in years of very plentiful water and of cold weather, snow and heavy rains at nesting time, suggests that cold and excessively wet springs may be more unfavourable to duck production than dry, warm springs.

The authors conclude that, for further progress in waterfowl population management, a more concerted effort is required to obtain information concerning age ratios of ducks by design and to relate these data to conditions on the breeding grounds.

\section{RADIOACTIVITY IN HUMAN DIET}

\begin{abstract}
THE possibility of early fall-out from recent bomb tests has focused attention on levels of iodine-131 in milk. However, since the saying, 'what goes up must come down' does not apply to short-lived isotopes, this danger has receded.

There is no such uncertuinty about the eventual return to Earth of materials such as strontium-90, and a reminder of this long-term hazard comes from the publication of the latest of five annual reports of the Agricultural Research Council (ARCRL 5). Figures are given for radioactivity due to strontium90 and cæsium-137 in dairy products, cereals and vegetablcs, and in soil samples taken at different depths. These figures will not reflect the effects of recent tests, but in conjunction with those from the previous reports may give some indication of the time for which radioactivity will persist in the diet after a future test ban.

The level of contamination rose to a peak in 1959 of $9.0 \mu \mu \mathrm{c}$. of strontium-90 per gm. of calcium in the average diet of the population of the United Kingdom. This was followed by a rapid fall to $6 \cdot 4 \mu \mu \mathrm{c}$. in 1960 ,
\end{abstract}

mainly due to the reduction of direct surface contamination of crops consequent on the cessation of testing in 1958.

The figures for 1960 were the result mainly of the absorption of radioactivity by plants, from the accumulated total in the soil, and more than 50 per cent of the total strontium-90 was found to be still in the upper layers of the soils tested.

Evaluation of these hazards is an uncertain matter. The level of strontium-90 in the bones of one-year-old children rose to $4 \mu \mu \mathrm{c}$. per gm. of calcium in 1959 . The most recent recommendation of the Medical Research Council (M.R.C. 1960, Rep. No. Cmnd. 1225 , H.M. Stationery Office) is "that if the concentration of strontium-90 in bone, calculated as an average for any age group, inc'uding the groups of infants and young children, was found to be rising continuously and to have reached the level of onehalf of that recommended as the maximum permissible level for the population as a whole $(67 \mu \mu c$. per gm. of calcium) a re-assessment of the situation would be required". 